\title{
雑草における除草剤感受性の種内変異と抵抗性発現
}

\author{
植木邦和, 山末祐二 \\ 京都大学農学部雑草学研究室 \\ (昭和 53 年 9 月 1 日受理)
}

\section{Intraspecific Variation of Weeds in Herbicide Susceptibility and Resistance Development}

\author{
Kunikazu Ueki and Yuji Yamasue \\ Weed Science Laboratory, Faculty of Agriculture, \\ Kyoto University, Kyoto 606, Japan
}

\section{は じめに}

ツマグロヨコバイの有機リン剤抵抗性, ニカメイチュ ウの BHC 抵抗性, いもち病菌のカスガマイシン抵抗性, ナシ黑斑病菌のポリオキシン抵抗性の発現など殺虫・殺 菌剤の連用によってそれまで感受性であっだ target 個 体群が薬剂抵抗性を発現した事例はきわめて多く認めら れていると同時に，この抵抗性発達がむしろ新規薬剤の 開発途上からすでに危惧されている. 一方, 除草郕の場 合, 雑草に対するその連用の影響は群落構成種の遷移と してとらえられるのが一般的で, ウリカワ (Sagittaria pygmaea), ホタルイ (Scirpus juncoides), ミズガヤツ リ (Cyperus serotinus) などこれまで潜在害草であった 多年生雑草が今日のように水田で問題化するのは一種の 除草剤連用の後遺症であり，いずれも競争種であった一 年生雑草が薬剤によって減少したこと, 手取り除草や中 耕の慣行がなくなったことなどのためで，これら多年生 雑草はいったん侵入すると強力な栄養繁殖力と薬戍抵抗 性をもって重要な害雑草となる1,2).

このほか, わが国においてこれまでのところ, 除草剂 による雑草防除の実用場面では作物の薬刜抵抗性品種間 差異を重要視することがあっても, 雑草の薬剤抵抗性あ るいは感受性の種内変異や抵抗性発現に関心を払うこと が少なく，またこれらに関する研究報告例も一，二にす ぎない.しかし，2，4-D や simazine などがわが国に導 入され, 耕地の化学的雑草防除に使用され始めて $20 \sim 23$
年が経過していることや, 数年以前から諸外国で雑草の $s$-triazine 抵抗性発現やその機構について頻繁に研究, 論 議されていることなどを考え，ここでは除草剤に対する 雑草の薬剤感受性種内変異や抵抗性発現について, 不備 な点があるが文献を中心にまとめてみた。

\section{抵抗性の発達条件と速度}

“雑草”とは，河野3によよれば，絶えず外的な干涉や生 育地の破壊が加えられている環境に生活する植物で, そ の多くが一年生草本によって占められ, 生殖システムも 自家受粉型が多く, 自家和合性も高い. また，ここでは “薬剤抵抗性（あるいは感受性）”を遺伝的変異にもとづ く生理, 生化学的なものとし, 薬郕からの逃避に関する 形態的, phenological なものは重要であるができるだけ 含めないこととした。

雑草が除草剂抵抗性を発達させる場合の機構は, 微生 物の抗性物質やサルファ剂抵抗性と同様に, (1) 薬剤作 用に対する耐性 (to withstand) の遺伝的適応，(2) 薬郕 による遺伝的抵抗性個体の選択に大別されると思われる が, 前者 (1) の機構は一般にバクテリアなど通常単細胞, 無性生殖の微生物に限られる4). 雑草の場合, 一般に 2 倍体, 多細胞で有性生殖を行なう高等植物であること, また形態的, 生理的形質や, 後に紹介するように薬戍感 受性に関して種内変異に富んでいることなどから後者 （2）の機構による薬剤抵抗性の発達が考えられる ${ }^{4 \sim 6)}$. すなわち，ある雑草の同種個体群が薬剤淘汰に曝された 
とき，それまで適応，競争力の劣るものとしてまれに存 在した抵抗性個体が，“正常な”感受性個体の淘汰の結 果, 繁殖, 優先化して, 個体群として薬剂抵抗性が発 達する．このときの第一義的条件はとうぜん，その個 体群に薬剤感受性の遺伝的变異が存在することである が，抵抗性の発達速度は薬郕の淘汰圧の大きさや期間， また個体群に打ける抵抗性遺伝子の頻度や優劣性, 突然 変異率, くみかえ価，さらに繁殖様式などに依存する ${ }^{5,7)}$. Haper ${ }^{4)}$ はある種の遺伝的変異は, その遺伝システムと異 系繁殖の頻度に基づくが，新しい系統を淘汰によって最 も速く分化させるものは効率よい異系繁殖によって变異 を増加させ，時打り同系繁殖によってそれを維持する個 体群であると指摘している. したがって，雑草のなかで おもに同系繁殖や栄養繁殖あるいはアポミクシスを行な う種に扒いてその速度が遅いと考えられるが，しかし、フ ポミクトの個体群であっても違った遺伝子型を含むとき 淘汰に反応する，また，後で述べるノボロギク (Senecio vulgaris) など多くの雑草のように，同系繁殖性の高い 種であっても，いったん，個体群に薬郕抵抗性の遺伝子 型が出現すると，この確実で迅速な繁殖法によって，遺 伝子型の頻度を維持できる ${ }^{5,8)}$.

雑草が種内変異に富み，また除草剂による雑草防除が 雑草発生前から発生初めにかけてかなりの完全防除主義 がとられるのにもかかわらず，病原菌や害虫の薬䯇抵抗 性発達にくらべて, 一般に雑草の薬剂抵抗性発達は速度 が遅いと考えられている。この理由として，Harper"), Radosevich and Appleby'), Ellis and Kay') らは, (1) 雑草の世代交代が一般に年間一世代であること，(2) 薬 棛感受性遺伝子の給源が淘汰に曝されてない土壌中の休 眠種子や近隣の同種個体群にあること，(3) 耕種的雑草 防除法の併用や除草剂の輪換があることなどを指摘して いる。ささらにわが国の水田の場合，一般に除草剂が単剂 でなく混合郕の型で使用されることや，雑草発生前処理 剂と生育中期処理郕がともに使用されることも薬郕抵抗 性の発達が遅い要因であると思われる。 2, 4-D が除草郕 として使用されはじめたのが 1940 年代である ${ }^{10)}$. 一方, イエバエは DDT に対して15 世代で抵抗性を発現した。 イェバェと雑草とではとうぜん，繁殖様式も個体群の大 きさも異なるが, King ${ }^{11)}$ はイエバエの DDT 抵抗性発現 の世代数から雑草の $2,4-\mathrm{D}$ 抵抗性発現は広範囲な 2, 4-D 連用後 15 年,すなわち 1960 1970 年であろうと述べた。 しかし，それまで殺草効果のあった薬量の 2,4-D が雑 草に対して効果不足をきたすようになったと報告された 例はこれより少し早く, 英国で 1954 年にエゾノキッネ アザミ(Cirsium arvense $)^{4,13)}$, ハワイのサトウキビ畑で
1956 年にダソドボロギク (Erechtites hieracifolia) $)^{4,12)}$ がある。また，より確からしい薬棛抵抗性個体群の出現 が米国 Washington 州で 1968 年，ノボロギクの simazine, atrazine 抵抗性に打いて発見されたのが，これら 薬戍の連用 10 年後であった ${ }^{13)}$.

\section{感受性の種内变異}

数多くの雑草の地域集団間に除草郕感受性についての 種内変異が認められている．たとえば，2，4-D に対する ダンドボロギク12), セイヨウヒルガオ (Convolvus arvensis) $)^{14,15)}$, ノラニンジン (Daucus carota $)^{16)}$, Cardaria chalepensis ${ }^{17)}$, dalapon に対するイヌビエ (Echinochloa crusgalli $)^{18)}$, dichlorprop に対するサナエ タデ(Polygonum lapathifolium $\left.)^{6}\right), 2,4-\mathrm{D}$, amitrole に 対するエゾノキッネアザミ ${ }^{19)}$, diallate, triallate, barban に 対するカラスムギ (Avena fatua) $)^{20)}$, MCPA, ioxynil に 対する一年生畑地雑草 Tripleurospermum inodorum ${ }^{21)}$, dalapon に対するセイバンモロコシ（Sorghum halepense $)^{22)}$ などがある。しかし，報告されたこれら雑草の 地域集団間に打ける薬郕感受性变異について，それが薬 剂による淘汰の結果か，あるいは薬剤と直接関係のない 環境要因によって誘導された遺伝子型分化の 2 次的影響 による結果かは多くの場合, 確証がない。

Harmmerton ${ }^{40)}$ は自殖型, 一年生雑草サナエタデの 5 地域集団間にフェノキシ除草郕 dichlorprop に対して LD L0 $_{50} 153 \pm 13.7$ から $318 \pm 32.8 \mathrm{mg} / \mathrm{m}^{2}$ の違いがあった と報告した。しかし，同時にこれらの集団間に他の形質 について変異があったことから，彼はこの dichlorprop に対する地域集団間変異は薬剂淘汰によるものでなく, 薬戍が直接関与しない遺伝子型分化によって生じたので ないかと考えた。な打茎葉処理剤の場合，雑草の薬郕感 受性は菱葉の表面積, 葉の重なり, 角度, ワックス・ク チクラ層の発達程度, 軟毛の有無, 気孔の分布・密度な ぞ薬郕保持に関する形態的形質が重要であり ${ }^{23)}$, しかも 雑草はその形態的形質变異に富んでいる。しかし，興味 深いことにほとえどの場合, 薬戍感受性の種内变異はそ の形態的形質の違いによって説明できない.

Sexsmith ${ }^{17)}$ は 1951 年から 1953 年にかけてカナダ Alberta 州に打ける Cardaria chalepensis 地域集団間 において 2,4-D butyl ester の殺草効果が顕著に異なる ことと同時に，この雑草の葉形態にも違いがあることに 気づいた．そこで彼はこれらの集団から 12 系統の $C$. chalepensis を選び，2,4-D，amitrole の固場試験を行な ったところ, amitrole $178 \mathrm{~g} / 10$ a で全系統が 95 99\%の 枯死株率を示したが，2,4-D の 89，178 g/10a ではそれ 
Table 1 Stand reduction of Cardaria chalepensis resulting from treatment with 2,4-D and amitrole (Adapted from Sexsmith, 1964) ${ }^{17}$.

\begin{tabular}{ccccc}
\hline & \multicolumn{3}{c}{ Percent stand reduction } \\
\cline { 2 - 3 } Strains & \multicolumn{2}{c}{$2,4-\mathrm{D}$} & & Amitrole \\
\cline { 2 - 3 } & $89 \mathrm{~g} / 10 \mathrm{a}$ & $178 \mathrm{~g} / 10 \mathrm{a}$ & & $178 \mathrm{~g} / 10 \mathrm{a}$ \\
\hline 1 & 0 & 85 & 99 \\
2 & 0 & 30 & & 96 \\
3 & 30 & 50 & & 95 \\
4 & 10 & 40 & & 99 \\
5 & 20 & 80 & & 99 \\
6 & 8 & 85 & 99 \\
7 & 3 & 30 & 99 \\
8 & 3 & 93 & 99 \\
9 & 3 & 65 & 99 \\
16 & 75 & 93 & 97 \\
18 & 0 & 10 & 96 \\
19 & 19 & 25 & 99 \\
\hline
\end{tabular}

Note: Stand reduction estimated one year after treatments applied in June, 1959, to the weed in the early- to full-bloom stages.

ぞれ 0 75\%, 10９3\% の系統間差を示した (Table 1). しかし，これら系統の薬郕感受性と茎葉部形態的形質, 株の発生密度や広がりなどとの相関はいずれの場合も有 意でなかった。また, Whitworth ${ }^{14)}$ は米国各地とカナダ で採取されたセイヨウヒルガオ種子から 51 系統のク口 ーンを得て 2,4-D 感受性の系統間差を調べた。 2, 4-D $134 \mathrm{~g} / 10 \mathrm{a}$ に対して最も感受性の大きいカナダの系統は 薬戍処理 1 力月後の生体重において処理前とくらべ 87 $\%$ 減少したが，最も感受性の小さかった New Mexico の系統は $87 \%$ 増加し，これらの間に連続した系統の薬 戍感受性があった。しかし，この薬剤感受性と系統の生 息地, 形態的形質, 生長速度, 再生力などとの関係は有 意でなかった. さらに Whitworth and Muzik ${ }^{15)}$ が上記 の最大, 最小の薬郕感受性をもった $\mathrm{S}$ と $\mathrm{R}$ 系統を供試し て実験を続けた結果，これらセイヨウヒルガオ植物体中 における 2,4-D- ${ }^{-14} \mathrm{C}$ の吸収, 移行 $\left({ }^{14} \mathrm{C}\right.$ で測定され，代 謝物は同定されなかった）に関して S， R系統間に有意 差が認められなかったが，茎断片を 2,4-D を含む寒天 で培養したとき $\mathrm{S}$ 系統では腋芽の生長がより抑制され， また基部に形成されたカルスが体積, 乾物重, 水分含量 においてR系統のそれの約 2 倍になることを認めた。こ れらのことは，2,4-Dに対するセイヨウヒルガオのこの 薬歳感受性系統間差は何らかの細胞レベルの生理, 生化 学的違いによるものと理解される. このように, 薬剂感
受性における雑草の地域集団あるいは系統間差の要因を 遺伝的な生理, 生化学的形質の变異に求めた事例はこの 他ノラニンジンの $2,4-\mathrm{D}$ 感受性 ${ }^{16)}$ やエゾノキッネアザ ミの 2,4-D あるいは amitrole 感受性 ${ }^{19,24)}$ な゙゙多数報告 されている.

Tripleurosperum inodorum はヨーロッパの大麦など の穀物畑で一般的に見られる一年生で，それぞれの地域 集団において種子のサイズや生長，開花習性などに大き な遺伝的適応性を示す雑草であって，自家不和合性の高 い異系繁殖種である ${ }^{6)}$. この雑草における除草刘感受性 の遺伝的変異性が Ellis and Kay6) によって調べられた。 英国南部とフランス北部の 6 地域集団から採喠された T. inodorum の系統は $\mathrm{ED}_{50}$ で $181 \pm 36.9$ から $73 \pm 17.3$ $\mathrm{mg} / \mathrm{m}^{2}$ にわたる MCPA 感受性変異を示した。最小の感 受性を示した系統はとれまで少なくとも 15 年間大麦な どの穀類栽培のために，MCPA を含めフェノキシ除草 戍を連用した固場の地域集団のものであり，また最大の 感受性を示した系統はジャガイモ围場から得られたもの でここでは穀類にだけフェノキシ除草剤を使用し，穀 類一双子葉作物の輪作が行なわれていた。 さらに，彼ら が系統数を 48 に増した実験報告によれば,フェノキシ 除草剂の使用歴の長い地域集団の系統は，短い使用歴や 未使用の集団のものにくらべ，明らかに大きい MCPA 抵抗性を示した。したがって，確かにいくらかの薬剤淘 汰が働いたと考えられる。しかし，この薬郕使用歴の異 なる系統間差よりも，同程度の薬剤使用歴をもった系統 間差のほうが大きく，また同時にどの地域においても使 用歴の短い ioxynil に対する薬剂抵抗性と MCPA 抵抗 性との間に高い相関があった。さらに，T. inodorum の形態的形質や薬戍保持量と MCPA, ioxynil 抵抗性と の間の何ら有意な関係は見いだせなかった。これらのこ とから, Ellis and Kay ${ }^{21)}$ は MCPA 抵抗性に関する $T$. inodorum 地域集団間差の大部分の要因は薬郕が関連し ない生理的形質の遺伝子型分化であり, 薬㣚淘汰の寄与 は少ないとした。 また，まったく作用機構が異なると考 えられている MCPA と ioxynil の抵抗性に正の相関が あったことは，殺菌，殺虫郕でよく認められる交差抵抗 性 ${ }^{38)}$ を示唆すると考えられるが，これを明らかにするた めには T. inodorum に打两薬刘の分解, 解毒機構 や薬戍抵抗性に関する遺伝子レベルの実験が必要であ る.

\section{抵抗性の発現}

雑草の地域集団間にも, また同一集団内部にもともに 薬郕感受性について種内变異がある5)。 また, Ellis and 
Table 2 Preemergence control of Senecio vulgaris from two locations with atrazine and simazine (Ryan, 1964) ${ }^{13}$ ).

\begin{tabular}{|c|c|c|c|}
\hline \multirow{3}{*}{ Herbicide } & \multirow{3}{*}{$\begin{array}{c}\text { Rate } \\
(\mathrm{kg} / \mathrm{ha})\end{array}$} & \multirow{2}{*}{\multicolumn{2}{|c|}{$\frac{\text { Control }(\%)^{\mathrm{a}}}{\text { Seed } \text { source }}$}} \\
\hline & & & \\
\hline & & A & B \\
\hline \multirow[t]{5}{*}{ Atrazine } & 0.28 & $\mathrm{NA}^{\mathrm{c}}$ & 46 \\
\hline & 0.56 & NA & 69 \\
\hline & 2.24 & 0 & 100 \\
\hline & 8.96 & 0 & NA \\
\hline & 17.92 & 0 & NA \\
\hline \multirow[t]{6}{*}{ Simazine } & 0.28 & $\mathrm{NA}$ & 62 \\
\hline & 0.56 & NA & 46 \\
\hline & 1.12 & NA & 100 \\
\hline & 2.24 & 0 & 100 \\
\hline & 8.96 & 0 & NA \\
\hline & 17.92 & 12 & NA \\
\hline
\end{tabular}

${ }^{a}$ Based on number of surviving seedlings related to number in check pots.

bource A, simazine or atrazine in use since 1958;

Source $\mathrm{B}$, triazine herbicides not in continuous use.

${ }^{\mathrm{N}} \mathrm{NA}=$ Herbicides not tested at these rates.

Kay ${ }^{25)}$, Hayes et al. ${ }^{26)}$, Karim and Bradshaw ${ }^{27)}$ らが報 告したように, 雑草や作物の個体群を人為的淘汰するこ こによっても除草剤抵抗性を大きくできる．また，T， inodorum の MCPA 抵抗性の地域集団間变異のように, 薬量でみた変異幅も小さく, どの程度薬剤の淘汰が寄与 するのか明らかでない場合が多い。これに対する一つの 要因は，多くの事例で薬剤が残効期間の短い 2,4-Dp MCPA などのフェノキシ除草戍であ ったことであると思われる。

しかし，1968 年米国 Washington 州, Puyallup の果樹 (?) 苗直において 比較的土袞残留期間の長い $s$-triazine 除草剂に対してきわめて大きい抵抗性 を示すノボロギクが発見された。ここ では，1958 年以来年間 1,2 回の散布 回数で 9 年間 simazine が雑草発生前 に連用され，10 年目に atrazine が雑 草発生後に使用されていた。この苗围 と $s$-triazine が連用されなかった國 場から採種したノボロギク（以下， Radosevich and Appleby ${ }^{28)}$ に準じ便 宜上，それぞれ R, S biotype とする) に対して simazine, atrazine の殺草効
果が調べられたところ，S biotype は simazine 1.12, atrazine $2.24 \mathrm{~kg} / \mathrm{ha}$ の発生前処理によって $100 \%$ 枯死し たのに対し， R biotype は両薬剤 $17.92 \mathrm{~kg} / \mathrm{ha}$ ，すなわ ち上記の 8 16 倍の薬量, で何ら肉眼的害徵を示さなか った (Table 2). また, $\mathrm{R}$ biotype は発生後 atrazine $4.48 \mathrm{~kg} / \mathrm{ha}$ 処理に対しても完全な抵抗性を示した。この 結果は 1970 年 $\operatorname{Ryan}^{13)}$ によって報告され，9 年間の雑 草発生前処理の simazine 連用によって抵抗性を発達さ せていたノボロギク個体群が 10 年目の発生後 atrazine 処理によってさらに選抜され，大きい抵抗性を示す $\mathrm{R}$ biotype が出現したのであるとされた. その後，上記の 苗圃の $\mathrm{R}$ biotype を防除するため 2 年間にわたり薬量 を増して atrazine を散布したところ，その薬剤抵抗性は さらに大きくなった．また，このノボロギクと同様に， atrazine 抵抗性を示すアカザ (Amaranthus retroflexus), イヌビユ (Chenopodium album) が報告されている ${ }^{31)}$ さらに, カナダ Ontario 州においても, atrazine を10 年 間連用したトウモロコシ畑で $20 \mathrm{~kg} / \mathrm{ha}$ の atrazine に抵 抗性を示すイヌビェ ${ }^{32)}$ ，アカザ ${ }^{33)}$ が相次いで発見されて いる (Fig. 1). 重大なことは，イスビユやアカザでみら れる atrazine 抵抗性が 1975 年に Ontario 州で約 300 haにわたっており，s-triazine 除草郕のトウモロコシ畑 における使用を許さなくなったということである ${ }^{33)}$. し かし，これら雑草の抵抗性は chlor-triazines だけでなく methoxy-あるいは methylthio-triazines にも共通である が，尿素，フェノキシ，ジニトロアニリン系など他の除 草剤に対してはそうでない。

一方，英国では Holliday and Putwain ${ }^{5)}$ が 6 10 年 間 simazineを連用した 60 以上の地域よりノボロギク，

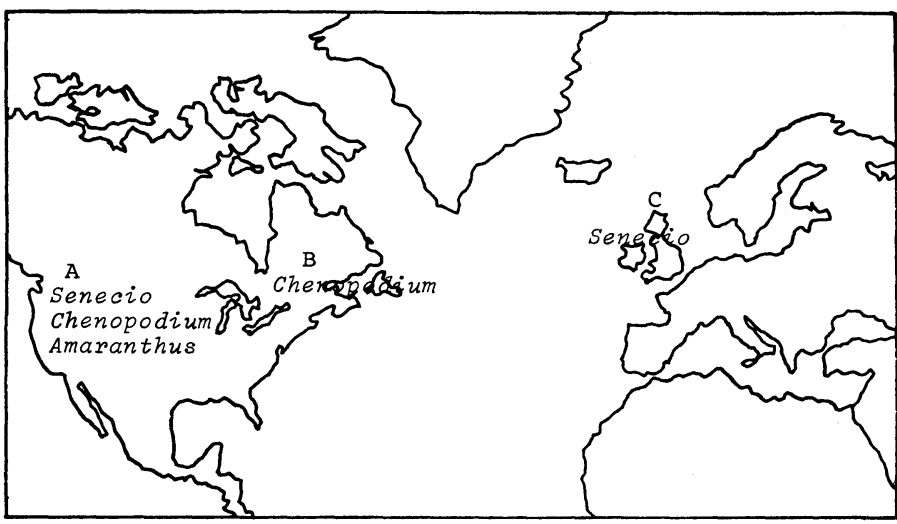

Fig. 1 Field selection for $s$-triazines. Resistance to atrazine and $s$-trazines has been found in three locations within 10 years of the repeated use (Adapted from Gressel and Segel, 1978 ${ }^{39}$ ): 松中昭一氏のご厚意により提供を受く). 
イヌビニ,ナズナ (Capsella bursa-pastoris) を採種し, それらの simazine 抵抗性変異を調査した. この結果, ノボロギクにおいて simazine 連用年数と明らかな関係 を示す薬戍抵抗性变異が認められたが， Ryan ${ }^{13)}$ の発見 したノボロギクの場合とくらべると，その变異幅はきわ めて小であった。この理由として彼らは（1）Ryanの発 見したノボロギクは simazine 連用期間の年間散布頻度 が多くまた最後の年に atrazine の雑草発生後散布がなさ れたこと，(2) 英国では年 1 回春季だけに simazine が 散布されるため秋季に発生するノボロギク実生が薬剤淘 汰から phenological に逃避できたことに加え，他の雑草 を防除するため paraquat のスポット処理が慣行された ことを指摘した。 な拉，最も大きい薬剤抵抗性を示した 集団に対して simazine による人為淘汰を行ない後代を 検定したところ，顕著な抵抗性の発達をみた。

\section{s-triazine 抵抗性の生理・生化学}

ノボロギクの $s$-triazine 抵抗性における $\mathrm{R}, \mathrm{S}$ biotype 間差は明らかに種子の発芽速度, 根系の深さ, あるいは
形態的形質などの違いによるものでなく，遺伝的な何ら かの生理, 生化学的形質によるものである.すなわち, 均一な大きさの水耕された実生に atrazine 根部処理して む R biotype は $30 \mathrm{ppm} の$ atrazine に対して何ら影響を 受けないが, S biotype は $0.5 \mathrm{ppm}$ でも茎葉部のクロロ ーシス,ネクローシスなど典型的害徵を呈し枯死する ${ }^{28)}$. また, R, S biotype 個体の間には ${ }^{14} \mathrm{C}$-simazine, -atrazine の吸収, 移行, 代謝における有意差はない29,30)。乙 かし，根部を $0.5 \mathrm{ppm}$ の simazine に浸漬したとき，S biotype $の \mathrm{CO}_{2}$ 固定速度による光合成量は顕著に抑制さ れたが， R biotype はまったく抑制を受けなかった (Fig. 2).

Radosevich and Devilliers ${ }^{30)}$ は R, S biotype から葉細 胞を単離し, それらの光合成や RNA, 蛋白, 脂質合成, あるいは葉緑体における光化学活性に対する atrazine の 影響を調べた. S biotype における光合成, RNA およ び脂質合成は $10 \mu \mathrm{M}$ の atrazine で抑制されたが， R biotype では抑制されなかった。 また，DCIP の還元量 で測定した葉緑体の光化学活性も S biotype が $5 \mu \mathrm{M}$ の

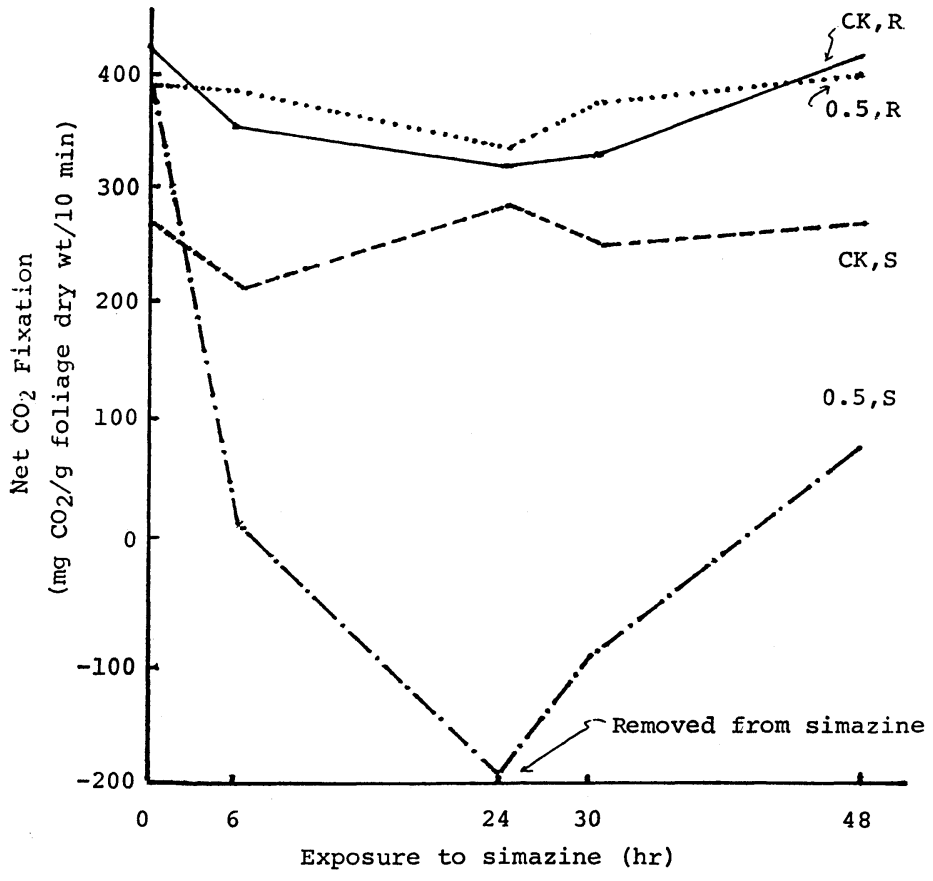

Fig. 2 Net $\mathrm{CO}_{2}$ fixation in resistant (R) and susceptible (S) biotypes of Senecio vulgaris, each exposed to $0.5 \mathrm{ppm}$ of simazine or untreated (CK). Averages of two replicated experiments. S biotype removed from simazine after $24 \mathrm{hr}$. LSD (0.05) values were $115,71,100$, and $67 \mathrm{mgCO}_{2} / \mathrm{g}$ dry foliage/ $10 \mathrm{~min}$ for 6 , 24, 30, and 48-hr exposure time, respectively (Radosevich and Appleby, 1973) ${ }^{29)}$. atrazine で顕著に抑制されるのに対し て，R biotype においては抑制されず むしろ 3 DCIP 還元量が増加すること が認められた。一般に,トウモロコシ， ソルガムなどの simazine, atrazine 抵 抗性植物と感受性植物との間の選択性 機構は, 植物体内での薬剤の分解, 抱 合による解毒作用にあり，抵抗性植物 であってもその単離葉緑体は薬剤に 対して感受性を示すことが知れてい る34,35). したがって，彼らは R biotype のノボロギクが薬剤抵抗性を示 す機構は, 葉緑体が関係するところで の薬剤の抱合不活性化にあるいは葉緑 体膜が薬剤分子に対して不透性である ことなどが考えられるとしている30). また同時に彼らは，無処理の R biotype 個体の光合成速度が S biotype よ り大きいことから，R biotype ではク ロロフィル分子の turn over rate が大 きいのではないかとしている.

Radosevich $^{36)}$ は atrazine 抵抗性を 発達させたアカザ，イヌビユに対して も上記と同様な実験結果を報告してい るが,イヌビユにおいて葉の $\mathrm{CO}_{2}$ 拡 散抵抗，とくに葉肉抵抗が atrazine 処 
理によって増加し，S biotype における光合成および蒸 散速度の抑制が R biotype のそれらとくらべ顕著である ことから，R biotype では薬剤分子が葉肉組織の細胞壁 あるいは膜に結合するとした報告 ${ }^{37) も あ る 。 ~}$

\section{おわりに}

現代農業における除草剂の役割はきわめて大きく，第 二次大戦後の先進国における生産性の飛躍的向上に除草 郕による化学的雑草防除が一翼をになっているといって も過言でない.しかし，最近問題となっている除草剤に よる環境污染のほか, 雑草草種の多年生への遷移, 薬剤 抵抗性雑草の出現などは薬剤のみによる雑草防除法に対 する自然の“巻き返し”である.

従来の「草をみずして草をとる」の防除理念より「草 を見てから草をとる」の発想の転換をはかるとともに， 多大の英知とエネルギーを消費して開発された優れた除 草剂を守るために，ただ無為に連用して雑草草種の遷移 や抵抗性の発現と新規薬剤導入をくり返すことはしてな らない. 雑草の除草剤に対する抵抗性発現を避けるため にも, Harper4) らが指摘するように, 雑草体内に打ける 作用点が限定されない薬剤, 突然变異性のない薬剤, 遅 効的であるより速効的な薬剤などを使用すべきであり， 相乗作用のある薬剂との併用, 作用機構の異なる薬郕と の輪換も行なう必要がある.また，われわれ雑草学の分 野においても, 雑草の薬郕感受性における種内変異や抵 抗性発現機構について研究する必要を痛感する.

\section{引用 文 献}

1）植木邦和・松中昭一：雑草防除大要, 養賢堂, p. 56,1977

2）日本植物調節剂研究協会：植調 12(2), 15 (1978)

3）河野昭一：種と進化，三省堂，p. 117，118，112, 1969

4) J. L. Harper: Proc. 3rd Br. Weed Control Conf., 179 (1956)

5) R. J. Holliday \& P. D. Putwain: Weed Res. 17, 291 (1977)

6) M. Ellis \& Q. O. N. Kay: Weed Res. 15, 307 (1975)

7）桐谷圭治・川原幸夫：植物防疫 24，474（1970）

8) D. Briggs \& S. M. Walters: Plant Variation and Evolution, George Weidenfeld and Nicolson Ltd., London, 1969 (D. ブリッグス・S. M. ウォルター ズ (広井敏男訳)：植物の変異と進化, 平凡社, p. 271, 1973)

9) S. R. Radosevich \& A. P. Appleby: Agron. J. 65, 553 (1973)
10) F. M. Ashton \& A. S. Craft: Mode of Action, John Wiley \& Sons, New York, p. 266, 1973

11) L. J. King: Weeds of the World, Interscience Publishers, Inc., New York, p. 238, 1966

12) N. S. Hanson: Weeds 10, 192 (1962)

13) G. F. Ryan: Weed Sci. 18, 614 (1970)

14) J. W. Whitworth: Weeds 12, 57 (1964)

15) J. W. Whitworth \& T. J. Muzik: Weeds 15, 275 (1967)

16) C. W. Whitehead \& C. M. Switzer: Can. J. Plant. Sci. 43, 255 (1963)

17) J. J. Sexsmith: Weeds 12, 19 (1964)

18) B. F. Roché Jr. \& T. J. Muzik: Agron. J. 56, 155 (1964)

19) J. M. Hodgson: Weed Sci. 18, 253 (1970)

20) R. Jacobson \& R. N. Andersen: Weed Sci. 16, 491 (1968)

21) M. Ellis \& Q.O. N. Kay: Weed Res. 15, 317 (1975)

22) G. W. Burt: Weed Sci. 22, 59 (1974)

23）植木邦和・山末祐二：「人間の生存にかかわる自 然環境に関する基礎的研究」研究報告集録, 東京 大学出版会, p. 262-263, 1976

24) J. M. Hodgson \& H. D. Moore: Weed Sci. 20, 68 (1972)

25) M. Ellis \& Q. O. K. Kay: Weed Res. 15, 327 (1975)

26) J. D. Hayes, R. K. Pfeiffer \& M. S. Rana: Weed Res. 5, 191 (1965)

27) A. Karim \& A. D. Bradshaw: Weed Res. 8, 283 (1968)

28) S. R. Radosevich \& A. P. Appleby: Agron. J. 65, 553 (1973)

29) S. R. Radosevich \& A. P Appleby: Weed Sci. 6, 497 (1973)

30) S. R. Radosevich \& O. T. Devilliers: Weed Sci. 24, 229 (1976)

31) D. Peabody: Weeds Today 5(2), 14 (1974)

32) J. D. Bandeen \& R. D. McLaren: Can. J. Plant. Sci. 56, 411 (1976)

33) V. S. Machado \& J. D. Bandeen: Weeds Today 9(2), 11 (1978)

34）松中昭一：化学総説, No. 2, 108 (1973)

35) D. E. Moreland, W. A. Gentner, V. L. Hilton \& K. L. Hill: Plant Physiol. 34, 432 (1959)

36) S. R. Radosevich: Weed Sci. 25, 316 (1977)

37) L. D. West, T. J. Muzik \& R. E. Witters: Weed Sci. 24, 68 (1976)

38）宮田 正・斉藤哲夫：日本農薬学会誌 3,179 (1978)

39) J. Gressel \& L. A. Segel: Proc. 4th IUPAC, IV-651 (1978)

40) J. L. Hammerton: Weed Res. 6, 132 (1966) 